\title{
ОСОБЛИВОСТІ ВІДБОРУ БАСКЕТБОЛІСТІВ НА ЕТАПІ СПЕЦАЛІЗОВАНОЇ БАЗОВОЇ ПІДГОТОВКИ
}

\author{
Микола Безмилов ${ }^{1}$, Оксана Шинкарук ${ }^{1}$, Шао Чжигон ${ }^{1}$ \\ ${ }^{1}$ Національний університет фізичного виховання і спорту України, Київ, Україна, kaupervud2020@ukr.net
}

https://doi.org/10.29038/2220-7481-2020-02-93-102

\begin{abstract}
Анотації
Ключовий фактор ефективності процесу багаторічного відбору та спортивної орієнтації в баскетболі - наявність інформативних критеріїв і показників, які відображають довгострокову перспективу юного спортсмена. Mema статті - проаналізувати критерії й особливості відбору баскетболістів на етапі спеціалізованої базової підготовки. Результати. Складність відбору в ігрових командних видах спорту пов'язана з тим, що в підлітковому віці зміст гри починає наближатися до умов спорту вищих досягнень. Перші 5-8 років присвячені переважно фізичній та технічній підготовці. Складні тактичні взаємодії, під час яких розкривається потенціал молодого гравця, збільшуються в навчально-тренувальному процесі в 14-17-річному віці. Спортсмени, яких за антропометричними, фізичними й технічними показниками вважали найперспективнішими в дитячому віці, утрачають свою перевагу над однолітками. Установлено, що критеріями для оцінювання спортивної обдарованості баскетболістів і подальшого відбору в рамках багаторічної системи спортивної підготовки рекомендовано використовувати тести та окремі показники, які характеризують рівень фізичної й технічної підготовленості баскетболістів. При цьому в процесі відбору майже не враховуються важливі ігрові здібності баскетболлістів, такі як ігровий інтелект й інтуїція, здатність до прийняття правильних рішень в умовах напруженої змагальної діяльності, уміння «бачити» майданчик та інші специфічні якості, які мають вирішальне значення на рівні спорту вищих досягнень. Практично всі рекомендовані в спеціальній літературі тестові завдання для визначення спортивної обдарованості баскетболістів мають допоміжний характер. Висновки. Під час відбору баскетболістів на етапі спеціалізованої базової підготовки та на інших етапах багаторічного вдосконалення потрібно враховувати рівень прояву специфічних ігрових здібностей баскетболістів, які не мають об'єктивно метричних одиниць вимірювання й потребують професійного експертного оцінювання.
\end{abstract}

Ключові слова: спортивний відбір, спортивні здібності, етапи багаторічного вдосконалення, змагальна діяльність, специфічні ігрові якості.

Николай Безмылов, Оксана Шинкарук, Шао Чжигон. Особенности отбора баскетболистов на этапе специализированной базовой подготовки. Ключевым фактором эффективности процесса многолетнего отбора и спортивной ориентации в баскетболе является наличие информативных критериев и показателей, которые отражают долгосрочную перспективу юного спортсмена. Цель работы - проанализировать критерии и особенностей отбора баскетболистов на этапе специализированной базовой подготовки. Результаты. Сложность отбора в игровых командных видах спорта связана с тем, что в подростковом возрасте содержание игры начинает приближаться к условиям спорта высших достижений. Первые 5-8 лет направлены преимущественно на физическую и техническую подготовку. Сложные тактические взаимодействия, при которых раскрывается потенциал молодого игрока, увеличиваются в учебно-тренировочном процессе в 14-17-летнем возрасте. Спортсмены, которых по антропометрическим, физическим и техническим показателям считали перспективными в детском возрасте, теряют свое преимущество над сверстниками. Установлено, что в качестве критериев для оценивания спортивной одаренности баскетболистов и дальнейшего отбора в рамках многолетней системы спортивной подготовки рекомендуется использовать тесты и отдельные показатели, которое преимущественно характеризуют уровень проявления физической и технической подготовленности баскетболистов. При этом в процессе отбора практически не учитываются важнейшие игровые способности баскетболистов, такие как игровой интеллект и интуиция, способность к принятию правильных решений в условиях напряженной соревновательной деятельности, умение «видеть» площадку и другие специфические игровые качества и умения, которые приобретают ведущее значение на уровне спорта высших достижений. Выводы. В процессе отбора баскетболистов на этапе специализированной базовой подготовки, а также на других этапах многолетнего совершенствования необходимо учитывать уровень проявления специфических игровых способностей баскетболистов, которые не имеют объективно метрических единиц измерения и требуют профессиональной экспертной оценки.

Ключевые слова: спортивный отбор, спортивные способности, этапы многолетнего совершенствования, соревновательная деятельность, специфические игровые качества.

Mykola Bezmylov, Oksana Shynkaruk, Shao Chzhyhon. The Selection Peculiarities of Basketball Players at the Specialized Basic Training Stage. The key factor of the effectiveness of the long-term selection process and sports 
orientation in basketball is the availability of informative criteria and indicators that reflect a long-term perspective of a young sportsman. The Research Aims to analyze the criteria and peculiarities of the basketball players' selection at the specialized basic training stage. The Research Results. The difficulty of selection in game team sports is related to the fact that in adolescence, the game content begins to approach to the terms of top sports achievements. The first 5-8 years are devoted mainly to physical and technical training. Complex tactical interactions, during which a young player's potential is revealed, increase in the educational and training processes at the age of 14-17. Sportsmen who were considered the most promising in childhood by their anthropometric, physical and technical parameters lose their advantage over their peers. It has been determined that as criteria for assessing the sports talent of basketball players and further selection within the long-term system of sports training, it is recommended to use tests and individual indicators that characterize the level of physical and technical preparedness of basketball players. At the same time, the selection process almost does not consider the important playing abilities of basketball players, such as game intelligence and intuition, ability to make the right decisions in conditions of intense competitive activity, the ability to «see» the playground and other specific qualities that play a crucial role at the top sports achievements level. Practically all the test tasks to determine the sports talent of basketball players recommended in the special literature have an auxiliary character. Conclusions. When selecting basketball players at the specialized basic training stage and at other stages of the long-term improvement, it is necessary to take into account the level of manifestation of specific game abilities of basketball players who do not have objectively metric units and need professional expert evaluation.

Key words: sports selection, sports abilities, stages of long-term improvement, competitive activity, specific game qualities.

Постановка проблеми та їі зв'язок із науковими планами та темами. Ефективність підготовки спортсменів в олімпійському спорті багато в чому залежить від правильно обраних стратегічних шляхів для подальшого вдосконалення, виявлення резервів її різних напрямів. Одним із них $\epsilon$ максимальна орієнтація на індивідуальні задатки та здібності спортсменів під час вибору спеціалізації, визначення раціональної структури змагальної діяльності, побудова всієї системи багаторічної підготовки. Це, зі свого боку, потребує якісного відбору та орієнтації підготовки спортсменів на всіх етапах багаторічного вдосконалення $[7 ; 8 ; 13 ; 14 ; 16 ; 22 ; 24 ; 26]$.

Ключовий фактор ефективності процесу багаторічного відбору й спортивної орієнтації в баскетболі - це наявність інформативних критеріїв та показників, які відображають довгострокову перспективу юного спортсмена $[1-4 ; 6 ; 10 ; 17 ; 30 ; 31]$.

Процес підготовки в баскетболі на першій стадії багаторічної спортивної кар'єри (становлення вищої майстерності) може тривати 12-15 років цілеспрямованої роботи. Складна структура змагальної діяльності та велика кількість різноманітних факторів, які можуть вплинути на спортивний результат у матчі, потребують урахування різноманітних критеріїв і показників, що важливі для визначення обдарованості юного спортсмена, його схильності до демонстрації високих спортивних результатів та тривалості виступів у спорті вищих досягнень $[3 ; 6 ; 9 ; 15 ; 18 ; 23 ; 29]$.

На перших етапах багаторічного вдосконалення визначити ігрову обдарованість спортсмена й перспективи його потрапляння до спорту вищих досягнень украй важко. Здійснювати відсів дітей на початковому етапі багаторічної підготовки досить ризиковано.

У деяких дослідженнях [14] задля оптимізації багаторічної підготовки рекомендовано після попереднього навчання різко зменшити кількість не придатних для виду спорту дітей (до десяти разів), уже починаючи 3 першого етапу підготовки (оптимальна модель поетапного відбору й формування резерву). На думку автора, це приведе до раціональної концентрації людського та фінансового потенціалу для повноцінного забезпечення підготовки найбільш обдарованих дітей i підлітків. Переваги такої теоретичної моделі багаторічної підготовки, із погляду спорту вищих досягнень, є цілком очевидними та зрозумілими.

Суттєвий недолік такого підходу - відсутність інформативних і надійних критеріїв визначення спортивної обдарованості дітей у багатьох видах спорту на першому етапі багаторічної підготовки. Надзвичайно складно встановити в 6-8-річному віці майбутніх спортсменів високого класу. Ризик такого масового відсіювання дітей на початкових етапах занадто великий. В ігрових командних видах спорту виконати перспективну оцінку гравця за попереднім навчанням практично неможливо. Наприклад, у країнах колишньої Республіки Югославії (Словенія, Хорватія тощо) відбір у групи починають лише 3 10-річного віку. Перші чотири роки діти навчаються технічних елементів, розвивають фізичні здібності, демонструють свою схильність до ігрової діяльності та перспективи подальшого зростання.

Складність відбору в ігрових командних видах спорту пояснюються ще й тим, що лише в підлітковому віці зміст гри починає наближатися до умов дорослого спорту. Тобто перші 5-8 років 
стосуються переважно фізичної й технічної підготовки. Складні тактичні взаємодії, під час яких і розкривається істинний потенціал молодого гравця, починають відчутно збільшуватися в навчальнотренувальному процесі набагато пізніше, у 14-17-річному віці. Спортсмени, яких за антропометриними, фізичними та технічними показниками вважали найперспективнішими в дитячому віці, утрачають свою перевагу над однолітками.

У зв'язку з цим дослідження й використання передового міжнародного досвіду та знань із проблем відбору баскетболістів на різних етапах багаторічної підготовки, їх поєднання з традиціями «української баскетбольної школи» $є$ важливими завданнями сьогодення. Саме тому, на нашу думку, проблема визначення інформативних критеріїв відбору баскетболістів на етапі спеціалізованої базової підготовки є актуальною та практично значущою.

Роботу виконано відповідно до Плану НДР НУФВСУ на 2016-2020 pp.

Мета роботи - проаналізувати критерії й особливості відбору баскетболістів на етапі спеціалізованої базової підготовки.

\section{Методи дослідження:}

- аналіз та узагальнення спеціальної науково-методичної літератури й практичного досвіду здійснювалися для визначення проблематики та узагальнення даних із питань спортивного відбору, орієнтації, підготовки спортсменів у різних видах спорту й баскетболі, вибору інформативних критеріїв і тестів для оцінки перспективних можливостей спортсменів на етапі спеціалізованої базової підготовки;

- опитування - це метод, що використовувався задля виявлення інформативних та надійних критеріїв визначення спортивної обдарованості молодих баскетболістів для вирішення питань стратегічних завдань підготовки резерву для спорту вищих досягнень). В опитуванні взяли участь 25 респондентів - тренерів із баскетболу (провідні тренери збірної команди України й тренери клубних команд: 20 - тренери вищої категорії, 5 - 1-ї категорії). Отримані результати дали підставу визначити думки тренерів щодо відповідності критеріїв і тестів етапу багаторічної підготовки;

- метод експертних оцінок застосовано для виявлення думки експертів стосовно визначення значущості й інформативності тестів для оцінки перспективних можливостей баскетболістів для етапів багаторічного вдосконалення, використано метод переваги (ранжування). Групова експертиза включала формулювання завдань, відбір і комплектування групи експертів, складання плану експертизи, проведення опитування експертів, аналіз та обробку отриманої інформації. Узгодженість думок експертів перевіряли за допомогою методу математичної статистики - розрахунку коефіцієнта конкордації Кендалла. Для підтвердження коефіцієнта конкордації, що характеризує середній ступінь узгодженості думок експертів, перевірялася його значимість за критерієм узгодження Пірсона ұ2-критерієм. Необхідність такої оцінки пов'язана з тим, що ми користуємося вибірковими даними (залучаємо не всіх фахівців, а їх групу, відтак отриманий результат може бути випадковим). Емпіричне значення $\chi 2$ емп порівнюємо $з$ табличним, що відповідає прийнятому рівню значущості $\alpha \mathrm{i}$ числа ступенів свободи $\mathrm{k}=\mathrm{n}-1$. Якщо $\chi 2$ емп> $\chi 2$ кр $(\alpha ; \mathrm{k})$, то коефіцієнт конкордації $\mathrm{W}$ істотний на обраному рівні значущості. У дослідженні взяли участь 20 експертів - тренерів із баскетболу вищої кваліфікації;

- статистичну обробка даних проводили за допомогою програмного пакета математичної статистики «Statistica 6.0» (StatSoft Inc., США, 1999) і редактора таблиць «Excel 2003» (Microsoft, США, 2003).

Результати дослідження. Один із найбільш складних етапів відбору в баскетболі - це відбір на етапі спеціалізованої базової підготовки (проміжний). Це період активного росту й дозрівання організму дитини. Етап підготовки характеризується значним підвищенням фізичних та ігрових навантажень. Значно збільшується роль тактичної підготовки. На попередніх етапах більшість тренувальних годин відводили загальному розвитку організму й технічній підготовці. У деяких країнах світу до віку 13-14 років тактичні взаємодії гравців, котрі є учасниками дорослого баскетболу, забороняють офіційно (PNR, зонну систему захисту тощо). Тобто основна увага повинна бути сконцентрована лише на базовій усебічній підготовці.

Звісно, за умови збільшення в навчально-тренувальному процесі складного матеріалу тактичної підготовки одразу ж стають помітні інтелектуальні ігрові здібності спортсменів і їх здатність до подальшого вдосконалення. У цей період можуть проявлятися такі здібності і якості, які існували в рудементальному стані на попередніх етапах підготовки.

Баскетболісти, котрі були найрозвинутішими на попередніх етапах, можуть утратити свою перевагу й зупинитися за крок від спорту вищих досягнень. Саме в цей період часу досить легко 
зробити помилку та відібрати не найбільш обдарованих спортсменів, а найбільш зрілих біологічно. Спортсмени-ретарданти значно поступаються своїм одноліткам. Потрібен час для того, щоб спортсмен зміг проявити свій справжній потенціал.

Одним із важливих завдань нашого дослідження було встановлення критеріїв і показників, які рекомендуються сьогодні теорією та практикою баскетболу задля відбору баскетболістів на етапі спеціалізованої базової підготовки (14-16 років), а також на інших етапах багаторічного вдосконалення, для комплектування команд і подальшого руху ієрархічною вертикаллю системи спорту вищих досягнень. Опитування тренерів $(\mathrm{n}=25)$ та експертна оцінка фахівців із баскетболу щодо значущості тестів на різних етапах багаторічного вдосконалення $(\mathrm{n}=20$, узгодженість думок експертів перевіряли за допомогою коефіцієнта конкордації $\mathrm{W}=0,76, \mathrm{p}<0,05$, значимість коефіцієнта конкордації $\mathrm{W}$ за критерієм узгодження Пірсона $\chi 2 \mathrm{eмп}=16,143, \mathrm{p}<0,05)$ дає нам підставу зробити низку припущень щодо того, що саме може впливати на існування тих протиріч, які виникають сьогодні під час відбору баскетболістів і визначення їхніх ігрових здібностей.

Одним із головних чинників, який, на наш погляд, стає причиною подальших проблем, пов'язаних із відбором та комплектуванням команд у цьому віці, $є$ вибір самих критеріїв визначення спортивної обдарованості гравця.

Ігрові командні види спорту (баскетбол, гандбол, футбол, хокей) мають надзвичайно складну структуру змагальної діяльності, яка характеризується різноманітністю ігрових дій, непередбачуваністю розвитку матчу й необхідністю в умовах дефіциту часу та альтернативи вибору під тиском протидії суперника приймати правильні техніко-тактичні рішення.

Визначальну роль для успішної змагальної діяльності при цьому відіграють інтелектуальні здібності спортсмена.

Традиційні критерії, які використовуються в багатьох видах спорту, у спортивних командних іграх не мають такої визначальної інформативності. Наприклад, показник $\mathrm{VO}_{2}$, котрий $\epsilon$ надзвичайно інформативним у багатьох циклічних видах спорту із метою відбору та побудови тренувального процесу, у командних спортивних іграх практично не використовується.

Із метою спортивного відбору гравців на різних етапах багаторічного вдосконалення українські баскетбольні тренери сьогодні використовують нормативні показники, представлені в спеціальній методичній літературі [2; 12] (Навчальна програма 3 виду спорту та ін.) (рис.1). Запропоновані критерії можна розподілити на декілька груп. Перспективність й обдарованість баскетболіста на етапі спеціалізованої базової підготовки переважно визначається за результатами складання комплексу тестових завдань. Це тести, у яких установлюємо швидкісно-силові й координаційні здібності, прояв загальної та спеціальної витривалості й техніко-тактичної підготовленості гравця. Для кожної групи тестів розроблено відповідні шкали оцінювання результатів.

Для успішного складання першої частини цих тестових завдань (тестування рухових здібностей) не обов'язково взагалі вміти грати в баскетбол. Швидкість бігу, розгинання рук в упорі лежачи або пробігання довгих дистанцій може бути використано, на наш погляд, із метою визначення стану готовності гравця на цей момент часу або задля спостерігання динаміки змін фізичної підготовленості спортсмена протягом тривалого часу тощо. Використання цих тестів задля спортивного відбору виглядає досить сумнівно. Особливо враховуючи той факт, що більшість із цих якостей піддається суттєвій корекції. Якщо використовувати ці тести для відбору баскетболістів на кожен наступний етап підготовки, то спостерігатимемо ситуацію, при якій більш фізично підготовлені та біологічно зрілі діти будуть отримувати найбільші рейтинги.

Під час відбору баскетболістів вже в підлітковому віці потрібно орієнтуватися на комплекс специфічних здібностей, котрі визначають подальшу можливість грати в дорослий баскетбол.

Дискусія. У середині вісімдесятих років XX ст. відомий канадський учений Роджер Бернслі [20] опублікував серію цікавих праць, у яких продемонстровано вплив періоду народження дитини в рамках календарного року на ії потрапляння до складу команд у хокеї, футболі та інших видах спорту. Цей феномен отримав у спортивній науці назву RAE (relate age effect). «Вплив ефекту віку» проявлявся в тому, що діти, які народилися в першій половині календарного року, мали більше шансів потрапити до складу команди в ігрових видах спорту для участі в змаганнях. На рівні спорту вищих досягнень цей дисбаланс повністю зникав. Бажаючи успішно виступити на змаганнях, тренери віддають перевагу більш біологічно зрілим спортсменам. Вплив «RAE» доведено в багатьох командних ігрових видах спорту і в подальших дослідженнях [18; 31]. 


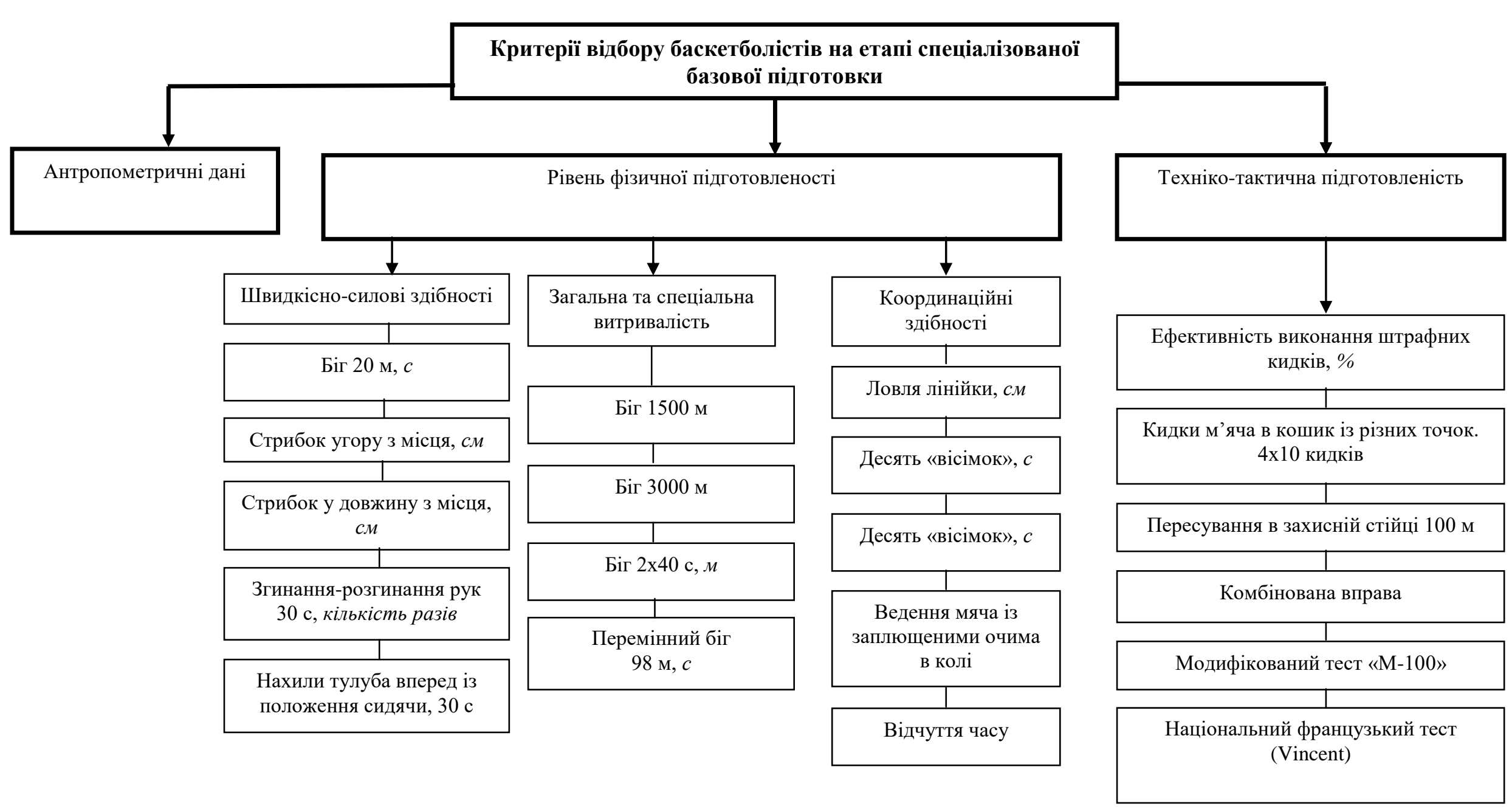

Рис. 1. Критерії та тести, які рекомендовано вітчизняними фахівиями для відбору баскетболістів на етапі спечіалізованої базової підготовки [2] 
Існування подібного феномену доведено й під час відбору та комплектування кадетських і юніорських баскетбольних команд у баскетболі [5; 19]. Перші міжнародні змагання з баскетболу для юнаків проходять у віковій категорії до 16 років (U 16). Практично всі збірні команди, які беруть участь у цих міжнародних змаганнях, мають у своєму складі близько 70-80 \% дітей, які народилися в першій половині календарного року. Після виступу на цих змаганнях більшість спортсменів зникають iз системи підготовки резерву для спорту вищих досягнень уже на наступному етапі (U 18) [5]. Тобто відсіюється до половини юнаків, які були відібрані тренерами в 15-16-річному віці для участі в міжнародних змаганнях. Досить часто можна почути від тренерів неофіційну назву чемпіонату Європи серед кадетських команд - «чемпіонат акселератів». Більш біологічно зрілі спортсмени перевершують своїх однолітків майже у всіх компонентах гри й набагато ефективніше ведуть змагальну діяльність.

Такий підхід практикується навіть у провідних баскетбольних країнах світу (Іспанії, Франції й ін.) і має свою логіку. Адже невдалий виступ кадетської збірної призводить до пониження в класі в змаганнях для майбутніх поколінь збірних. Звичайно, можна сформувати склад юніорської команди лише 3 найбільш перспективних гравців, із погляду майбутніх виступів у спорті вищих досягнень, $\mathrm{i}$ виступати на цих змаганнях, незважаючи на підсумковий результат. Однак проблема у цьому випадку буде полягати в тому, що багато хто з таких гравців, ще не готовий до швидкостей, атлетизму та психологічної напруги подібних міжнародних матчів.

Дослідження, проведені D. Marinkovic [27] та S. Ostojic [28], показали, що рівень прояву $\mathrm{VO}_{2}$ у баскетболістів високого класу, які виступають на позиціях «важкого форварда» та центрового, не має такого значення порівняно навіть із чоловіками, які спортом не займаються. Гравці захисту виконують значний обсяг бігової роботи та мають найвищий рівень МСК у команді, однак жоден із фахівців не вказує на важливу роль показників функціональної підготовленості під час відбору в команду.

Практично всі рекомендовані в спеціальній літературі тестові завдання для визначення спортивної обдарованості баскетболістів мають допоміжний характер. У цих тестах не визначаються ігрові здібності спортсмена. Навіть та група тестів, яка рекомендована фахівцями для встановлення рівня техніко-тактичної підготовленості (див рис.1), не відображає спеціальних ігрових здібностей і не може бути застосована з метою відбору баскетболістів.

Ігрова обдарованість та перспективність молодого баскетболіста оцінюються під час гри або ігрових модельних епізодів, максимально наближених до умов змагальної діяльності. Можна безліч разів влучати в кошик під час тестових завдань наодинці або ефективно вести м'яч поміж стійок, однак при цьому не зуміти реалізувати свої технічні навички в грі. Проведені дослідження 3 цієї проблеми [4] показали, що результати виконання тестових кидкових завдань не мають суттєвих кореляційних зв'язків із виконанням тих самих кидків під час реальної гри.

Автори навіть змоделювали пульсові режими виконання кидків у тестах на тренуваннях $\mathrm{i}$ максимально наблизили їх до змагальних умов. Попри це, відсоток улучань кидків у тестових завданнях був набагато вищим, ніж під час гри (майже у два рази). I справа не лише в тому, як вважають автори, що більша психологічна напруга вплинула на такий дисбаланс. В умовах реальної гри, для того, щоб виконати кидок, спортсмену потрібно зробити значну кількість тактичних взаємодій із партнерами по команді й переміщень, подолати супротив захисників команди суперника, які не дають змоги вільно виконати ці кидки.

Відомий ізраїльський фахівець із баскетболу Арік Шівек [32], який сьогодні очолює систему підготовки національних збірних команд Ізраїлю, вважає, що доля показників фізичної підготовленості під час відбору баскетболістів на наступний етап уже на рівні кадетських збірних не може перевищувати 30 \% від загального внеску чинників, які визначають перспективність гравця.

Під час здійснення відбору сьогодні не враховують надважливі ігрові здібності баскетболістів. Здатність гравця приймати правильні ігрові рішення в захисті та нападі - можливість грати під тиском суперника та «читати» гру, володіння творчими ігровими здібностями, ефективність гри один в один у захисті та нападі й ін.

Ці специфічні ігрові здібності не мають об’єктивно-метричних одиниць вимірювання (с, см, \%). Однак при цьому вони відіграють вирішальну роль для подальших спортивних звершень та можуть інколи повністю компенсувати недоліки технічної й фізичної підготовленості, невідповідність модельним антропометричним даним тощо.

У спорті вищих досягнень показники змагальної діяльності можуть надати повноцінну інформацію під час визначення таких здібностей. У підлітковому віці, особливо враховуючи проблеми біологічного дозрівання, такий підхід утрачає свою надійність. 
Очевидна необхідність створення комплексної системи відбору баскетболістів, яка б ураховувала різні сторони підготовленості спортсменів з урахуванням їх пріоритетної значущості для визначення перспективних баскетболістів, здатних потрапити до спорту вищих досягнень. Особлива роль у цій системі відбору баскетболістів має бути відведена оцінюванню специфічних ігрових здібностей, які не мають об’єктивно-метричних одиниць вимірювання.

Висновки. Ефективність відбору баскетболістів на етапі спеціалізованої базової підготовки багато в чому залежить від наявності інформативних і надійних критеріїв визначення спортивної обдарованості молодих виконавців. Це, зі свого боку, уможливить відбір для подальшого вдосконалення найбільш перспективних гравців із погляду стратегічних завдань підготовки резерву для спорту вищих досягнень.

Складна структура змагальної діяльності в ігрових командних видах спорту вимагає врахування під час відбору специфічних якостей і можливостей спортсменів, які проявляються переважно лише в реальних ігрових умовах під час складних взаємодій між гравцями команди. Рекомендовані сьогодні в спеціальній літературі критерії й тести задля відбору баскетболістів на етапі спеціалізованої базової підготовки не дають змоги повною мірою розкрити справжній ігровий потенціал спортсмена. Комплекс тестових завдань, спрямованих на визначення рівня фізичних можливостей і технічної підготовленості, доцільніше використовувати для оцінювання стану готовності гравця на цей момент та із метою вивчення динаміки змін протягом тривалого періоду часу, оцінювання ефективності запропонованих засобів тренувального впливу тощо.

Визначення специфічних ігрових здібностей баскетболістів на етапі спеціалізованої базової підготовки та інших етапах багаторічного вдосконалення потребує високого рівня професійної майстерності від тренера, який здійснює подібне оцінювання. Оскільки подібне оцінювання обдарованості гравця завжди матиме суб'єктивний характер, потрібно мінімізувати вірогідність допущення селекційної помилки шляхом залучення достатньої кількості фахівців із баскетболу та подальшої експертної обробки отриманих результатів.

Перспективи подальших досліджень пов'язані 3 визначенням комплексу інформативних показників, які відображають специфічні ігрові здібності баскетболістів задля їх подальшого використання для відбору на етапі спеціалізованої базової підготовки та прогнозування перспектив потрапляння молодих спортсменів у спорт вищих досягнень.

\section{Джерела та література}

1. Бабушкин В. 3. Специализация в спортивных играх. Киев: Здоровья, 1991. 161 с.

2. Баскетбол: навч. прогр. для ДЮСШ, СДЮШОР та ШВСМ. (навчально-тренувальні групи та групи спортивного вдосконалення)/Держкомспорт України; підготували: Л. Ю. Поплавський, В. Г. Окіпняк. Київ, 1999. 126 с.

3. Безмылов Н., Шинкарук О., Мурзин Е. Система отбора игроков и подготовка резерва для национальной сборной команды по баскетболу. Спортивний вісник Придніпров'я. 2016. № 1. С. 5-14.

4. Безмилов М., Шинкарук О. Педагогічне тестування баскетболістів різної кваліфікації та ігрових амплуа для ефективності змагальної діяльності. Теорія і методика фізичного виховання $і$ спорту. 2011. № 3. C. $8-12$.

5. Безмылов Н. Н. Влияние «эффекта возраста» на отбор спортсменов и комплектование составов молодежных команд в игровых видах спорта. Наука в олимпийском спорте. 2017. № 2. С. 17-22.

6. Бриль М. С. Отбор в спортивных играх. Москва: «ФиС», 1980. 126 с.

7. Запорожанов В. А., Кузьмин А. И., Дьяченко В. Ф. Система отбора (селекции) важнейший фактор формирования резерва для олимпийской подготовки. Современный олимпийский спорт: тезисы докладов междунар. науч. конгресса. Киев, 10-15 мая 1993 г. Киев, 1993. С. 136-8.

8. Иссурин В. Б. Подготовка спортсмена XXI века. Научные основы и построение тренировки. Москва: Спорт, 2016. $464 \mathrm{c}$.

9. Латышкевич Л. А. Подготовка спортсменов высокой квалификации в спортивных играх. Киев, 1992.

10. Луничкин В. Г. Методология подготовки олимпийского резерва в баскетболе. Теория и практика физической культуры. 1991. № 7. С. 52-3.

11. Лысенко Е. Н. Особенности структуры функциональной подготовленности высококвалифицированных баскетболистов различной специализации. Наука в олимпийском спорте. 2010. № 1-2. С. 80-6.

12. Мітова О. О., Сушко Р. О. Методи наукових досліджень у баскетболі [навч.-метод. посіб. для студентів вищ. навч. закл. фіз. культури і спорту]. Дніпропетровськ: Вид-во «Інновація», 2015. 216 с.

13. Николаенко В. В. Рациональная система многолетней подготовки футболистов к достижению высшего спортивного мастерства: монография. Киев: Саммит-книга, 2014. 336 с. 
14. Платонов В. Н. Система подготовки спортсменов в олимпийском спорте. Общзая теория и ее практические приложения: учеб. в 2 кн. Киев: Олимп. лит., 2015. кн. 1. 680 с.

15. Стонкус С. С. Теоретические и методические основы спортивной подготовки баскетболистов: автореф. дис... д-ра пед. наук: спец. 13.00.04. Теория и методика физического воспитания, спортивной тренировки и оздоровительной физической культуры. Москва: ГЦОЛИФК, 1987. 46 с.

16. Шинкарук О. А. Отбор спортсменов и ориентация их подготовки в процессе многолетнего совершенствования (на материале олимпийских видов спорта): монография. Киев: Олимп. лит., 2011. 360 с.

17. Abdelkrim B.N., Fazaa S.E., Ati J.A. Time-motion analysis and physiological data of elite under-19-year-old basketball players during competition. British Journal of Sports Medicine. 2007. 41:69-75. http://doi.org/10,1136/ bjsm.2006.032318

18. Apostolidis N., Nassis G. P., Bolatoglou T., Geladas N. D. Physiological and technical characteristics of elite young basketball players. J Sports Med. Phys. Fitness 4. 157-163, 2004.

19. Arrieta H., Torres-Unda J., Gil S.M. \& Irazusta J. Relative age effect and performance in the U16, U18 and U20 European basketball championships. Journal of Sports Sciences. 2016. V. 34. P. 1530-1534. http://dx.doi.org/10.1080/02640414.2015.1122204

20. Barnsley R. H., Thompson A. H., Bamsley R. E. Hockey success and birthdate: The relative age effect. Canadian Association for Health, Physical Education, and Recreation. 1985. 51(1). P. 23-28. http://doi.org/ $10.1177 / 1012690210371560$

21. Billie J. M. Basketball. Theory and Practice/Moore J. Billie. White O. John. 1980. 306.

22. Bompa T. Total Training for Young Champions. Champaign, IL: Kinetics H, editor. 2000.

23. Dežman B., Erćult F., Vućković G.. Classifying young basketball players into playing positions with chosen anthropometric and motor variables. 3rd International scientific conference Kinesiology new perspectives, Opatija, Croatia, September 25-29, 2002, proceedings book. Kinesiology: new perspectives: proceedings book Zagreb: Faculty of kinesiology, University of Zagreb, 2002. P. 943-946.

24. Erculj F., Blas M., Bracic M. Physical demands on young elite European female basketball players with special reference to speed, agility, explosive strength, and take-off power. J Strength Cond Res. 2010.24 (11). 2970-2978. URL: http://doi.org 10.1519 / JSC.0b013e3181e38107.

25. Jeličić M., Sekulić D., Marinković M. Anthropometric characteristics of high level European junior basketball players. Collegium Antropologicum. 26. 2002. P. 69-76.

26. Kostiukevych V., Shchepotina N., Zhovnych O., Shynkaruk O., Koliadych Yu., Hatsoieva L., Voronova V., Vozniuk T., Kaplinskyi V., Diachenko A., Chernyshenko T., Konnova M. Highly Qualified Grass Hockey Sportswomen's Adaptation to Training Intensity in the Macrocycle Preparatory Period. Journal of Physical Education and Sport. 2020. Vol 20 (1). Art 55. P. 385-394. URL: http://doi.org 10.7752/jpes.2020.s1055

27. Marinkovic D., Pavlovic S. The differences in aerobic capacity of basketball players in different playing positions. Physical Education and Sport. 2013. V. 11 (1). P. 73-80.

28. Ostojic S. M., Mazic S., Dikic N. Profiling in basketball: Physical and physiological characteristics of elite players. The Journal of Strength \&Conditioning Research. 2006. 20 (4). P. 740-744. URL: http://doi.org/ 10.1519/00124278-200611000-00003

29. Stroganov S., Serhiyenko K., Shynkaruk O., Byshevets N., Denysova L., Yukhno Yu., Stepanenko O., Ulan A. Features of preventive activity at the initial stage of training of many years standing of young basketball player. Journal of Physical Education and Sport. 2020. Vol 20 (1). Art 66 pp 452-455. URL: http://doi.org/ 10.7752/jpes.2020.s1066

30. Torres-Unda J., Zarrazquin I., Gil J., Ruiz F., Kortajarena A., Seco M., Irazusta J. Anthropometric, physiological and maturational characteristics in selected elite and non-elite male adolescent basketball players. Journal of Sports Science. 2013. 31 (2). P. 196-203. URL: http://doi.org/10.1080 / 02640414.2012.725133

31. Vučković I., Kukrić A., Petrović B., Dobraš R. Relative age effect and selection of young basketball players. Physical culture. 2013. 67(2). P. 113-119.

32. Shivek A. Player selection for young national teams in Israel. URL: https://www.youtube.com/watch? $=16$ DqwHUwf6M

\section{References}

1. Babushkyn, V. Z. (1991). Spetsyalyzatsyya v sportyvnykh yhrakh. Kiyev: Zdorov'ya, 161.

2. Basketbol: Navch. prohrama dlya DYUSSH, SDYUSHOR ta SHVSM. (navchal'no-trenuval'ni hrupy ta hrupy sportyvnoho vdoskonalennya)/Derzhkomsport Ukrayiny. Pidhotuvaly: L. YU. Poplavs'kyy, V. H. Okipnyak. Kyiv, 126.

3. Bezmylov, N., Shynkaruk, O., Murzyn, E. (2016). Systema otbora yhrokov y podhotovka rezerva dlya natsyonal'noy sbornoy komandy po basketbolu. Sportyvnyy visnyk Prydniprov'ya, 1, 5-14.

4. Bezmylov, M., Shynkaruk, O. (2011). Pedahohichne testuvannya basketbolistiv riznoyi kvalifikatsiyi ta ihrovykh amplua dlya efektyvnosti zmahal'noyi diyal'nosti. Teoriya $i$ metodyka fizychnoho vykhovannya $i$ sportu, 3, 8-12. 
5. Bezmylov, N. N. (2017). Vlyyanye «éffekta vozrasta» na otbor sportsmenov y komplektovanye sostavov molodezhnykh komand v yhrovykh vydakh sporta. Nauka v olympyyskom sporte, 2, 17-22.

6. Bryl' M. S. Otbor v sportyvnykh yhrakh. Moskva: «FyS», 1980. 126.

7. Zaporozhanov, V. A., Kuz'myn, A. Y, D'yachenko, V. F. (1993). Systema otbora (selektsyy) vazhneyshyy faktor formyrovanyya rezerva dlya olympyyskoy podhotovky. Sovremennyy olympyyskyy sport: Tezysy dokladov mezhdunarodnoho nauchnoho konhressa. Kyev, 10-15 maya 1993 h. Kyev, 136-8.

8. Yssuryn, V. B. (2016). Podhotovka sportsmena XXI veka. Nauchnye osnovy y postroenye trenyrovky. Moskva: Sport, 464.

9. Latyshkevych, L. A. (1992). Podhotovka sportsmenov vysokoy kvalyfykatsyy v sportyvnykh yhrakh. Kyiv.

10. Lunychkyn, V. H. (1991). Metodolohyya podhotovky olympyyskoho rezerva v basketbole. Teoryya y praktyka fyz. kul'tury, 7, 52-3.

11. Lysenko, E. N. (2010). Osobennosty struktury funktsyonal'noy podhotovlennosty vysokokvalyfytsyrovannykh basketbolystov razlychnoy spetsyalyzatsyy. Nauka v olympyyskom sporte, 1-2, 80-6.

12. Mitova, O. O., Sushk, o R. O. (2015). Metody naukovykh doslidzhen' u basketboli [navch.-metod. posibnyk dlya studentiv vyshchykh navchal'nykh zakladiv fizychnoyi kul'tury i sportu]. Dnipropetrovs'k: Vyd-vo «Innovatsiya», 216.

13. Nykolaenko, V. V. (2014). Ratsyonal'naya systema mnoholetney podhotovky futbolystov k dostyzhenyyu vyssheho sportyvnoho masterstva: Monohrafyya. Kyiv: Sammyt-knyha, 336.

14. Platonov, V. N. (2015). Systema podhotovky sportsmenov v olympyyskom sporte. Obshchaya teoryya y ee praktycheskye prylozhenyya: uchebnyk v 2 kn. Kyev: Olymp. lyt., 1, 680.

15. Stonkus, S. S. (1987). Teoretycheskye y metodycheskye osnovy sportyvnoy podhotovky basketbolystov: avtoref. dys... d-ra ped. nauk: spets. 13.00.04. Teoryya y metodyka fyzycheskoho vospytanyya, sportyvnoy trenyrovky y ozdorovytel'noy fyzycheskoy kul'tury. Moskva: HTSOLYFK, 46.

16. Shynkaruk, O. A. (2011). Otbor sport·smenov y oryentatsyya ykh podhotovky v protsesse mnoholetneho sovershenstvovanyya (na materyale olympyyskykh vydov sporta): monohrafyya. Kyiv: Olymp. lyt., 360.

17. Abdelkrim, B. N., Fazaa, S. E., Ati, J. A. (2007). Time-motion analysis and physiological data of elite under19-year-old basketball players during competition. British Journal of Sports Medicine, 41, 69-75. http://doi.org/10,1136 / bjsm.2006.032318

18. Apostolidis, N., Nassis, G. P., Bolatoglou, T., Geladas, N. D. (2004). Physiological and technical characteristics of elite young basketball players. J Sports Med. Phys. Fitness, 4, 157-163.

19. Arrieta, H., Torres-Unda, J., Gil, S. M. \& Irazusta, J. (2016). Relative age effect and performance in the U16, U18 and U20 European basketball championships. Journal of Sports Sciences, 34, 1530-1534. http://dx.doi.org/10.1080/02640414.2015.1122204

20. Barnsley, R. H., Thompson, A. H., Bamsley, R. E. (1985). Hockey success and birthdate: The relative age effect. Canadian Association for Health, Physical Education, and Recreation, 51(1), 23-28. http://doi.org// $10.1177 / 1012690210371560$

21. Billie, J. M. (1980). Basketball. Theory and Practice/Moore J. Billie. White O. John, 306.

22. Bompa, T. (2000). Total Training for Young Champions. Champaign, IL: Kinetics H, editor.

23. Dežman, B., Erćult, F., Vućković, G. (2002). Classifying young basketball players into playing positions with chosen anthropometric and motor variables. 3rd International scientific conference Kinesiology new perspectives, Opatija, Croatia, September 25-29, 2002, proceedings book. Kinesiology: new perspectives: proceedings book Zagreb: Faculty of kinesiology, University of Zagreb, 943-946.

24. Erculj, F., Blas, M., Bracic, M. (2010). Physical demands on young elite European female basketball players with special reference to speed, agility, explosive strength, and take-off power. J Strength Cond Res, 24 (11), 2970-2978. http://doi.org 10.1519/JSC.0b013e3181e38107.

25. Jeličić, M., Sekulić, D., Marinković, M. (2002). Anthropometric characteristics of high level European junior basketball players. Collegium Antropologicum, 26, 69-76.

26. Kostiukevych, V., Shchepotina, N., Zhovnych, O., Shynkaruk, O., Koliadych, Yu., Hatsoieva, L., Voronova, V., Vozniuk, T., Kaplinskyi, V., Diachenko, A., Chernyshenko, T., Konnova, M. (2020). Highly Qualified Grass Hockey Sportswomen's Adaptation to Training Intensity in the Macrocycle Preparatory Period. Journal of Physical Education and Sport. 20 (1), 55, 385-394. http://doi.org 10.7752/jpes.2020.s1055

27. Marinkovic, D., Pavlovic, S. (2013). The differences in aerobic capacity of basketball players in different playing positions. Physical Education and Sport, 11 (1), 73-80.

28. Ostojic, S. M., Mazic, S., Dikic, N. (2006). Profiling in basketball: Physical and physiological characteristics of elite players. The Journal of Strength \&Conditioning Research, 20 (4), 740-744. http://doi.org/10.1519/ 00124278-200611000-00003

29. Stroganov, S., Serhiyenko, K., Shynkaruk, O., Byshevets, N., Denysova, L., Yukhno, Yu., Stepanenko, O., Ulan A. (2020). Features of preventive activity at the initial stage of training of many years standing of young 
basketball player. Journal of Physical Education and Sport, 20 (1), 66, 452-455. http://doi.org/10.7752/ jpes.2020.s1066

30. Torres-Unda, J., Zarrazquin, I., Gil, J., Ruiz, F., Kortajarena, A., Seco, M., Irazusta, J. (2013). Anthropometric, physiological and maturational characteristics in selected elite and non-elite male adolescent basketball players. Journal of Sports Science, 31 (2), 196-203. http://doi.org/10.1080 / 02640414.2012.725133

31. Vučković, I., Kukrić, A., Petrović, B., Dobraš, R. (2013). Relative age effect and selection of young basketball players. Physical culture, 67(2), 113-119.

32. Shivek, A. Player selection for young national teams in Israel. https://www.youtube.com/watch?v $=16$ DqwHUwf6M

Стаття надійшла до редакції 24.03.2020 p. 